\title{
Efficacy and safety of stem cell therapy in patients with dilated cardiomyopathy: a systematic appraisal and meta-analysis
}

Shu-Ling Rong ${ }^{1}$, Ze-Kun Wang ${ }^{2}$, Xue-Dong Zhou², Xiao-Lin Wang ${ }^{3^{*}}$, Zhi-Ming Yang ${ }^{1}$ and Bao Li $i^{*}$

\begin{abstract}
Background: The clinical significance of stem cell therapy in the treatment of dilated cardiomyopathy remains unclear. This systemic appraisal and meta-analysis aimed to assess the efficacy and safety of stem cell therapy in patients with dilated cardiomyopathy. After searching the PubMed, Embase, and Cochrane library databases until November 2017, we conducted a meta-analysis to evaluate the efficacy and safety of stem cell therapy in patients with dilated cardiomyopathy.
\end{abstract}

Methods: The weighted mean difference (WMD), standard mean difference (SMD), relative risk (RR), and 95\% confidence interval $(\mathrm{Cl})$ were summarized in this meta-analysis. Both fixed effects and random effects models were used to combine the data. Sensitivity analyses were conducted to evaluate the impact of an individual dataset on the pooled results.

Results: A total of eight randomized controlled trials, which involved 531 participants, met the inclusion criteria in this systematic appraisal and meta-analysis. Our meta-analysis showed that stem cell therapy improves left ventricular ejection fraction $\left(\mathrm{SMD}=1.09,95 \% \mathrm{Cl} 0.29\right.$ to $\left.1.90, \mathrm{P}^{2}=92 \%\right)$ and reduces left ventricular end-systolic volume $\left(\mathrm{SMD}=-0.36,95 \% \mathrm{Cl}-0.61\right.$ to $\left.-0.10, \mathrm{P}^{2}=20.5 \%\right)$ and left ventricular end-diastolic chamber size $(\mathrm{SMD}=-0.48,95 \%$ $\mathrm{Cl}-0.89$ to $\left.-0.07, \mathrm{I}^{2}=64.8 \%\right)$ in patients with dilated cardiomyopathy. However, stem cell therapy has no effect on mortality $\left(\mathrm{RR}=0.72,95 \% \mathrm{Cl} 0.50\right.$ to $\left.1.02, \mathrm{P}^{2}=30.2 \%\right)$ and 6 -min-walk test $(\mathrm{WMD}=51.52,95 \% \mathrm{Cl}-24.52$ to 127.55 , $\left.r^{2}=94.8 \%\right)$.

Conclusions: This meta-analysis suggests that stem cell therapy improves left ventricular ejection fraction and reduces left ventricular end-systolic volume and left ventricular end-diastolic chamber size in patients with dilated cardiomyopathy. However, future well-designed large studies might be necessary to clarify the effect of stem cell therapy in patients with dilated cardiomyopathy.

Keywords: Stem cell therapy, Dilated cardiomyopathy, Meta-analysis, Systematic appraisal

\footnotetext{
*Correspondence: czsrsl@sina.com; libaoxys@163.com

1 Department of Cardiology, The Second Hospital of Shanxi Medical

University, Taiyuan, Shanxi, People's Republic of China ${ }^{3}$ Department of Neonatology, The Second Hospital of Shanxi Medical University,

Taiyuan, Shanxi, People's Republic of China

Full list of author information is available at the end of the article
} 


\section{Background}

Cardiomyopathies represent a complex group of heterogeneous heart muscle diseases caused by mechanical and/or electrical dysfunction, usually manifesting as inadequate ventricular hypertrophy or dilatation [1]. Dilated cardiomyopathy is characterized by the presence of left ventricular chamber enlargement and contractile dysfunction without abnormal stress conditions and severe coronary artery disease [2, 3]. Dilated cardiomyopathy is the third major cause of heart failure and the most frequent indication for heart transplant worldwide, with a prevalence of 40 in 100,000 persons and an annual incidence of seven in 100,000 persons [1, $4,5]$. Dilated cardiomyopathy can occur irrespective of the sex and ethnic group; in dilated cardiomyopathy, the systolic capacity of the left ventricular decreases and the patient often suddenly dies; about half of the people are reported to have died within 5 years of diagnosis [6].

Current treatments for dilated cardiomyopathy, such as beta-blockers, angiotensin receptor antagonists, angiotensin-converting enzyme inhibitors, and mechanotherapy, are aimed at reducing the rate of damage to the myocardium and not increasing its regenerating potential. Thus, the development of new therapeutic methods for this condition is required for this significant, unmet medical need. Over the last one and half decades, several stem cell studies have been conducted in patients with cardiovascular disease who underwent autologous and allogeneic stem cell transplantation using various stem cell types and have used numerous strategies for the management of stem cell deficiency [7]. Autologous bone marrow stem cell implantation in coronary artery has been proven to be safe and effective in improving the cardiac function of patients with infarction and chronic ischemia in preclinical and clinical conditions $[8,9]$. Greatly reduced coronary blood flow reserve and restricted microvascular function have been found in patients with dilated cardiomyopathy $[10,11]$. Several clinical studies have shown the safety of cell therapy in these patients $[12,13]$, although there's still some controversy over the underlying mechanisms [14-16] and specific procedures at the methodological level $[13,17]$. To provide a comprehensive assessment of the effects of stem cells therapy in patients with dilated cardiomyopathy, we aimed to perform a systematic appraisal and meta-analysis of published studies.

\section{Methods}

The present meta-analysis was performed in accordance with the Preferred Reporting Items for Systematic Reviews and Meta-analysis guidelines [18].

\section{Search strategy}

We searched for relevant studies in the Embase, PubMed and Cochrane Library databases from January 1990 to November 2017. The following search terms were used: "dilated cardiomyopathy", "dilative cardiomyopathy", "stem cell", "bone marrow cells", "mesenchymal stem cell", "hematopoietic stem cells", "progenitor stem cell", "mother cells", and "colony forming units". Two reviewers independently searched the above mentioned databases, and the third reviewer resolved all disputes about eligibility. The article search was not limited by study design; however, only articles published in English were searched. All scanned summaries, studies, and quotations were reviewed. In addition, a manual cross retrieval of the bibliography of the retrieved manuscripts was conducted to further search for relevant publications.

\section{Selection criteria}

Studies that (1) involved patients with dilated cardiomyopathy; (2) used at least two comparison groups, that is, one group that received stem cell therapy/transplantation and another group that received control treatment without stem cell therapy/transplantation; (3) were published in English; and (4) used mortality and left ventricular ejection fraction (LVEF) as primary outcome measures and left ventricular end-systolic volume (LVESV), left ventricular end-diastolic chamber size (LVEDCS), and 6-min-walk test as second outcome measures were included. Studies that (1) used the same population or overlapping database and (2) were performed in animal models were excluded.

\section{Data extraction and quality assessment}

Two researchers independently extracted data from individual studies based on the descriptions provided by the authors of the included studies. Any disagreement was resolved by discussion, and a third author was consulted where necessary. The following data were obtained from each article: first author, year of publication, country, mean age, intervention, time of follow-up, study design, and outcomes assessed. When results were presented in a figure, we used GetData Graph Digitizer 2.25 (http:// getdata-graph-digitizer.com) to determine the exact values. The quality of randomized controlled trials (RCTs) was assessed using the Cochrane Collaboration's tool for assessing risk of bias [19]. The assessment included the following components: random sequence generation, blinding of patients and study personnel, allocation concealment, blinding of outcome assessment, selective reporting of outcomes, completeness of outcome data, and other threats to validity. 


\section{Statistical analysis}

The meta-analysis was performed using Stata 12.0 (StataCorp, College Station, TX, USA). The standard mean difference (SMD)/weighted mean difference (WMD) and 95\% confidence intervals (CI) were calculated for the continuous data, and the risk ratio (RR) and 95\% confidence intervals were calculated for dichotomous data. Q-statistics and $I^{2}$ index were used to evaluate the heterogeneity between various effects. The heterogeneity was at $I^{2}>50 \%$, which was statistically significant. The random-effects model was used in the analysis. By contrast, we used a fixed-effects model to calculate the summary effect. We conducted a series of sensitivity analyses to estimate the influence of each study by omitting one study at a time. We used STATA 12.0 software to perform
Begg's and Egger's test to quantify the publication bias. Significant publication bias was defined as a two-sided $P$ value of $<0.05$, which was statistically significant.

\section{Results}

Study selection

As demonstrated in Fig. 1, from our electronic search, we identified 125 studies. We found one additional study by cross-referencing the reference lists of other relevant articles. According to the inclusion criteria, 101 studies were retained after removing the duplicates. Fifty-two articles, whose titles or abstracts were screened, were excluded as the studies were irrelevant. Of the remaining 49 articles, 33 were excluded as they were categorized as letters, reviews, and
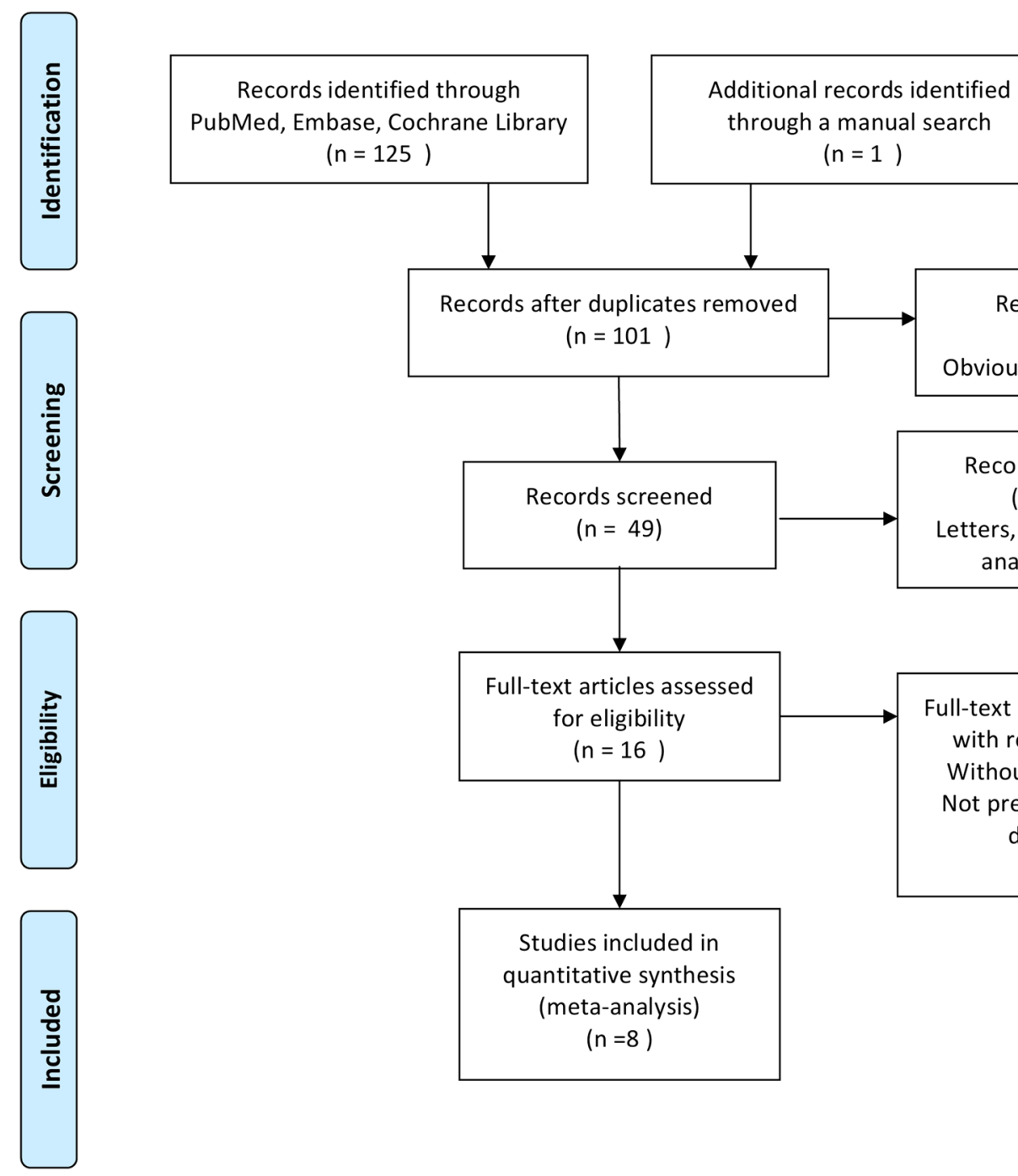
through a manual search $(n=1)$
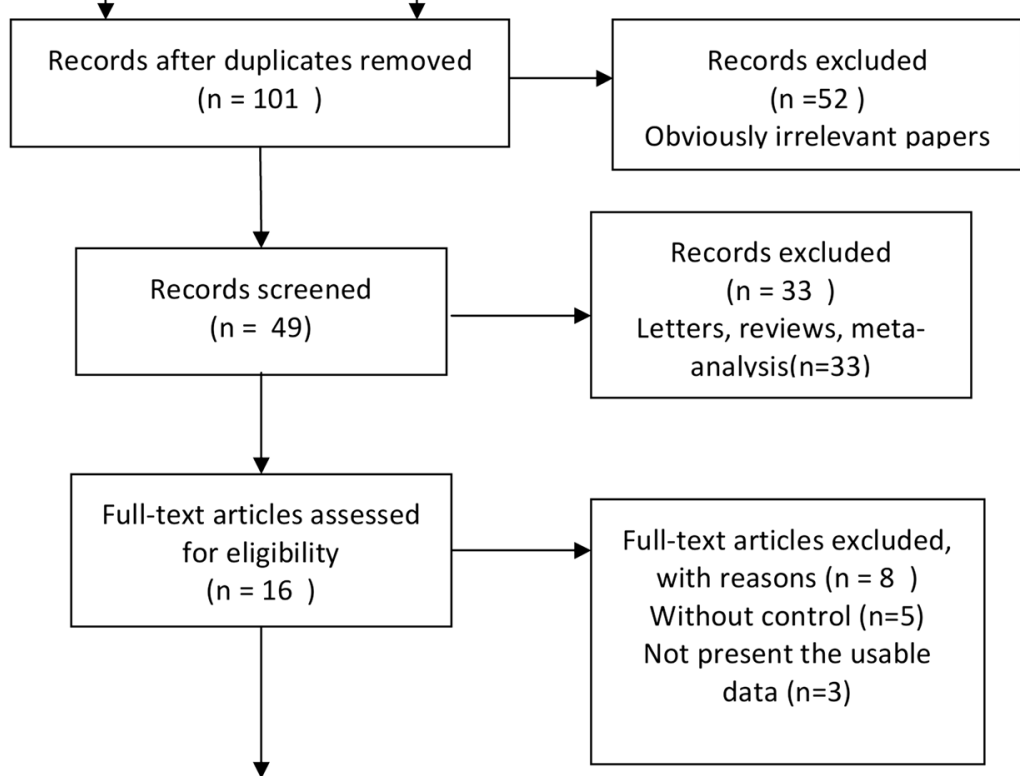

Studies included in quantitative synthesis (meta-analysis) $(n=8)$

Fig. 1 Flow diagram of studies identification 
meta-analyses. The remaining 16 studies were evaluated in detail. Eight of these studies were excluded, of which five had no control group and three did not present the usable data. As a result, only eight randomized controlled trials $[14,20-26]$ with 524 participants that fulfilled our inclusion criteria were analyzed.

\section{Characteristics of the studies}

The eight RCTs assessed 531 participants, including 276 participants who received stem cell therapy and 255 controls. The characteristics of the studies are shown in Table 1. The included articles were published between 2010 and 2017. The average age of patients in each trial ranged from 45 to 57.9 years old (Table 1 ). We also used a tool recommended by the Cochrane Collaboration to assess for risk of bias. A graph and summary of selection bias, detection bias, performance bias, reporting bias, attrition bias, and other bias identified in each RCT are shown in Figs. 2 and 3. Three studies lacked allocation concealment, five studies lacked blinding to participants, and one study lacked blinding to outcome assessment.

\section{Quantitative synthesis Mortality}

Eight articles involving 471 participants presented the mortality data. The heterogeneity test indicated that there was no statistical heterogeneity $\left(P_{\text {heterogene- }}\right.$ ity $\left.=0.187, I^{2}=30.2 \%\right)$, and there was no significant differences in mortality ( $R R=0.72,95 \%$ CI 0.50 to 1.02 ) (Fig. 4) between the stem cell therapy group and control group.

\section{LVEF}

Eight articles involving 398 participants presented the LVEF data. The heterogeneity test indicated that there was significant statistical heterogeneity $\left(P_{\text {heterogene- }}\right.$ ity $<0.001, I^{2}=92 \%$ ), and a significant increase in LVEF (SMD $=1.09,95 \%$ CI 0.29 to 1.90 ) (Fig. 5) was observed in the stem cell therapy group compared with the control group.

Table 1 Characteristics of the studies included in this meta-analysis

\begin{tabular}{|c|c|c|c|c|c|c|c|c|}
\hline \multirow{2}{*}{$\begin{array}{l}\text { Authors/year } \\
\text { of publication }\end{array}$} & \multirow[t]{2}{*}{ Country } & \multirow[t]{2}{*}{ Male (\%) } & \multirow[t]{2}{*}{ Mean age } & \multicolumn{2}{|c|}{ Intervention } & \multirow[t]{2}{*}{ Follow-up } & \multirow[t]{2}{*}{ Study design } & \multirow[t]{2}{*}{ Outcomes assessed } \\
\hline & & & & Stem cell & Control & & & \\
\hline Seth/2010 [20] & India & 83.9 & $\begin{array}{l}\text { Stem cell: } 45 \pm 15 \text { years } \\
\text { Control: } 49 \pm 9 \text { years }\end{array}$ & 41 & 40 & $36 \mathrm{M}$ & $\mathrm{RCT}$ & $\begin{array}{l}\text { Mortality, LVEF, LVEDCS, } \\
\text { and LVESV }\end{array}$ \\
\hline Vrtovec/2011 [14] & USA & 79 & $53 \pm 9$ years & 28 & 27 & $12 \mathrm{M}$ & $\mathrm{RCT}$ & $\begin{array}{l}\text { Mortality, LVEF, LVEDCS, } \\
\text { and 6-min-walk test }\end{array}$ \\
\hline Vrtovec/2013 [21] & USA & 81 & $54 \pm 9$ years & 55 & 55 & $60 M$ & $\mathrm{RCT}$ & $\begin{array}{c}\text { Mortality, LVEF, LVEDCS, } \\
\text { and 6-min-walk test }\end{array}$ \\
\hline Henry/2014 [22] & USA & 68.9 & $\begin{array}{l}\text { Stem cell: } \\
57.9 \pm 11 \text { years } \\
\text { Control: } 52.3 \pm 11 \text { years }\end{array}$ & 18 & 11 & $12 \mathrm{M}$ & $\mathrm{RCT}$ & $\begin{array}{l}\text { Mortality, LVEF, LVESV, and } \\
\text { 6-min-walk test }\end{array}$ \\
\hline Sant Anna/2014 [23] & Brazil & 60 & $\begin{array}{l}\text { Stem cell: } \\
48.3 \pm 8.71 \text { years } \\
\text { Control: } \\
51.6 \pm 7.79 \text { years }\end{array}$ & 20 & 10 & $12 \mathrm{M}$ & $\mathrm{RCT}$ & $\begin{array}{l}\text { Mortality, LVEF, LVESV, } \\
\text { LVEDCS, and 6-min-walk } \\
\text { test }\end{array}$ \\
\hline Hamshere/2015 [26] & UK & 75.8 & $\begin{array}{l}\text { Stem cell: } \\
57.67 \pm 12.32 \text { years } \\
\text { Control: } \\
56.79 \pm 9.84 \text { years }\end{array}$ & 15 & 14 & $12 \mathrm{M}$ & $\mathrm{RCT}$ & $\begin{array}{l}\text { Mortality, LVEF, LVEDCS, } \\
\text { and LVESV }\end{array}$ \\
\hline Martino/2015 [24] & Brazil & 70.6 & $\begin{array}{l}\text { Stem cell: } \\
51 \pm 11.1 \text { years } \\
\text { Control: } \\
49.6 \pm 11.1 \text { years }\end{array}$ & 82 & 78 & $12 \mathrm{M}$ & $\mathrm{RCT}$ & $\begin{array}{l}\text { Mortality, LVEF, LVESV, and } \\
\text { 6-min-walk test }\end{array}$ \\
\hline Xiao/2017 [25] & China & 75.6 & $\begin{array}{l}\text { Stem cell: } \\
51.6 \pm 12.2 \text { years } \\
\text { Control: } \\
54.4 \pm 11.6 \text { years }\end{array}$ & 17 & 20 & $12 \mathrm{M}$ & $\mathrm{RCT}$ & $\begin{array}{c}\text { Mortality, LVEF, LVEDCS, } \\
\text { and 6-min-walk test }\end{array}$ \\
\hline
\end{tabular}

LVEDCS left ventricular end-diastolic chamber size, LVEF left ventricular ejection fraction, LVESV left ventricular end-systolic volume, $M$ months, NA not available, RCT randomized controlled trial 


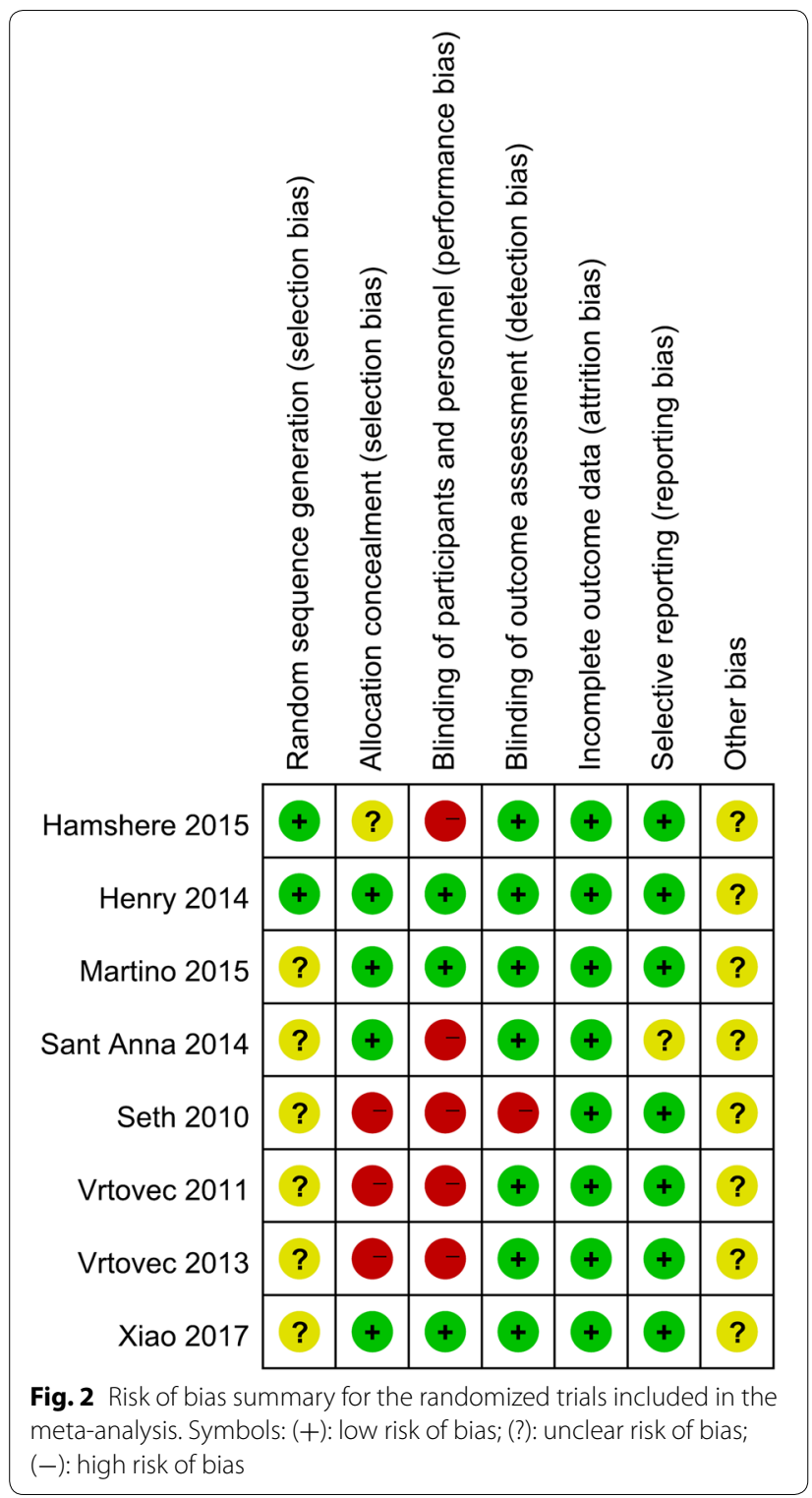

LVESV

Five articles involving 248 participants presented the LVESV data. The heterogeneity test indicated that there was no statistical heterogeneity $\left(P_{\text {heterogeneity }}=0.284\right.$, $\left.I^{2}=20.5 \%\right)$, and a significant decrease in LVESV $(\mathrm{SMD}=-0.36,95 \% \mathrm{CI}-0.61$ to -0.10$)$ (Fig. 6) was observed in the stem cell therapy group compared with the control group.

\section{LVEDCS}

Seven articles involving 310 participants presented the LVEDCS data. The heterogeneity test indicated that there was a significant statistical heterogeneity $\left(P_{\text {heteroge- }}\right.$ neity $=0.009, I^{2}=64.8 \%$ ), and the outcome showed that a significant decrease in LVEDCS was observed between the two groups $(\mathrm{SMD}=-0.48,95 \% \mathrm{CI}-0.89$ to -0.07$)$ (Fig. 7).

\section{6-min-walk test}

Five articles involving 384 participants presented the 6-min-walk test data. The heterogeneity test indicated that there was significant statistical heterogeneity $\left(P_{\text {het- }}\right.$ erogeneity $<0.001, I^{2}=94.8 \%$ ), and no significant difference was observed in the 6-min-walk test between the two groups (WMD $=51.52,95 \% \mathrm{CI}-24.52$ to 127.55$)$ (Fig. 8).

\section{Sensitivity analysis}

We performed a series of sensitivity analyses by sequentially deleting each qualifying study to assess the impact of a single dataset on the pooled results. As seen in Figs. 9, 10, 11, 12, and 13, any individual study was omitted, but the overall statistical significance remained unchanged, suggesting that our results were statistically robust.

Random sequence generation (selection bias)

Allocation concealment (selection bias)

Blinding of participants and personnel (performance bias)

Blinding of outcome assessment (detection bias)

Incomplete outcome data (attrition bias)

Selective reporting (reporting bias)

Other bias
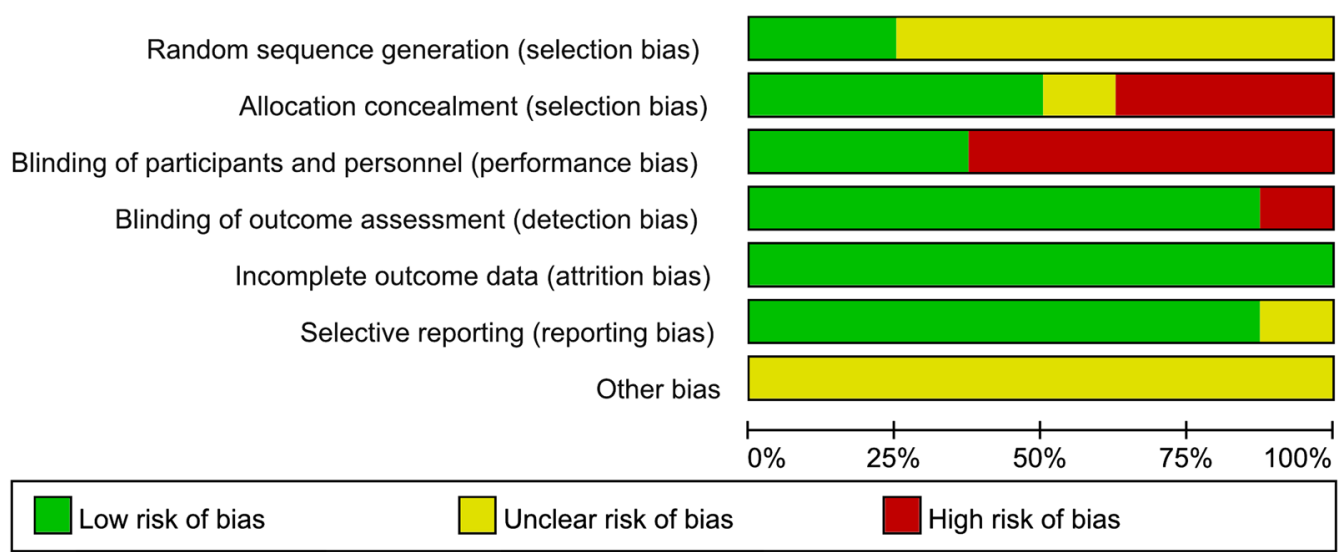

Fig. 3 Risk of bias graph for the randomized trials included in the meta-analysis 


\section{Study}

ID

Seth (2010)

Vrtovec (2011)

Vrtovec (2013)

Henry (2014)

Sant Anna (2014)

Hamshere (2015)

Martino (2015)

Xiao (2017)

Overall (I-squared $=30.2 \%, p=0.187$ )

\section{$\mathrm{RR}(95 \% \mathrm{Cl}) \quad$ Weight}

$0.84(0.44,1.58) \quad 24.26$

$0.24(0.06,1.03) \quad 13.94$

$0.42(0.20,0.88) \quad 32.52$

$0.56(0.03,12.23) \quad 1.93$

$3.15(0.45,21.96) \quad 2.36$

$5.00(0.26,95.02) \quad 0.86$

$1.05(0.51,2.14) \quad 19.98$

$0.21(0.01,4.10) \quad 4.16$

$0.72(0.50,1.02) \quad 100.00$

Fig. 4 Forest plot of the mortality of stem cell therapy versus controls in patients with dilated cardiomyopathy

\section{Study}

ID

Seth (2010)

Vrtovec (2011)

Vrtovec (2013)

Henry (2014)

Sant Anna (2014)

Hamshere (2015)

Martino (2015)

Xiao (2017)

Overall (I-squared $=92.0 \%, p=0.000)$

NOTE: Weights are from random effects analysis

\section{$-4.04 \quad$ Stem cell ${ }^{0}$ Control}

$\%$

SMD $(95 \% \mathrm{Cl}) \quad$ Weight

Fig. 5 Forest plot of the LVEF of stem cell therapy versus controls in patients with dilated cardiomyopathy 


\section{Study}

ID
$\%$

$\operatorname{SMD}(95 \% \mathrm{Cl}) \quad$ Weight

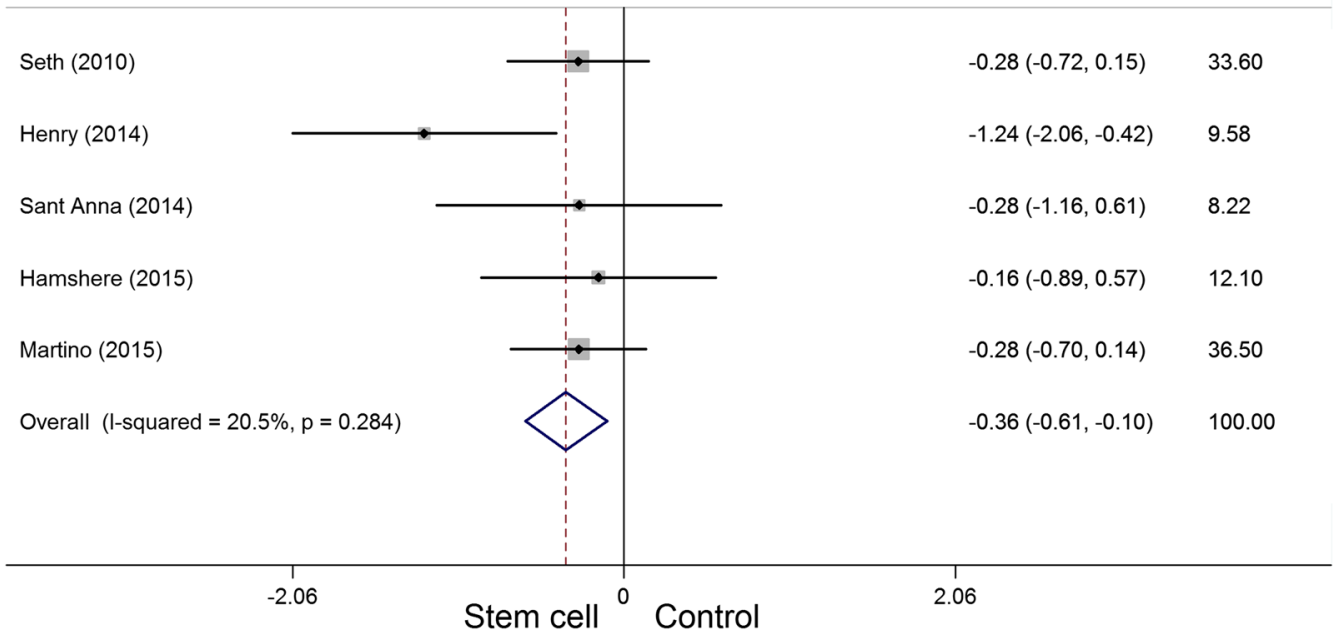

Fig. 6 Forest plot of the LVESV of stem cell therapy versus controls in patients with dilated cardiomyopathy

Study
ID

Fig. 7 Forest plot of the LVEDCS of stem cell therapy versus controls in patients with dilated cardiomyopathy

\section{Publication bias}

Publication bias in literature was assessed by funnel plot, Begg's and Egger's test. As shown in Figs. 14, 15, 16, 17, and 18, there was no evidence of publication bias for mortality (Begg's test: $P=0.902$; Egger's test: $P=0.875$ ),
LVEF (Begg's test: $P=0.386$; Egger's test: $P=0.425$ ), LVESV (Begg's test: $P=0.462$; Egger's test: $P=0.448$ ), LVEDCS (Begg's test: $P=0.230$; Egger's test: $P=0.589$ ), and 6-min walk test (Begg's test: $P=0.806$; Egger's test: $P=0.417)$. 


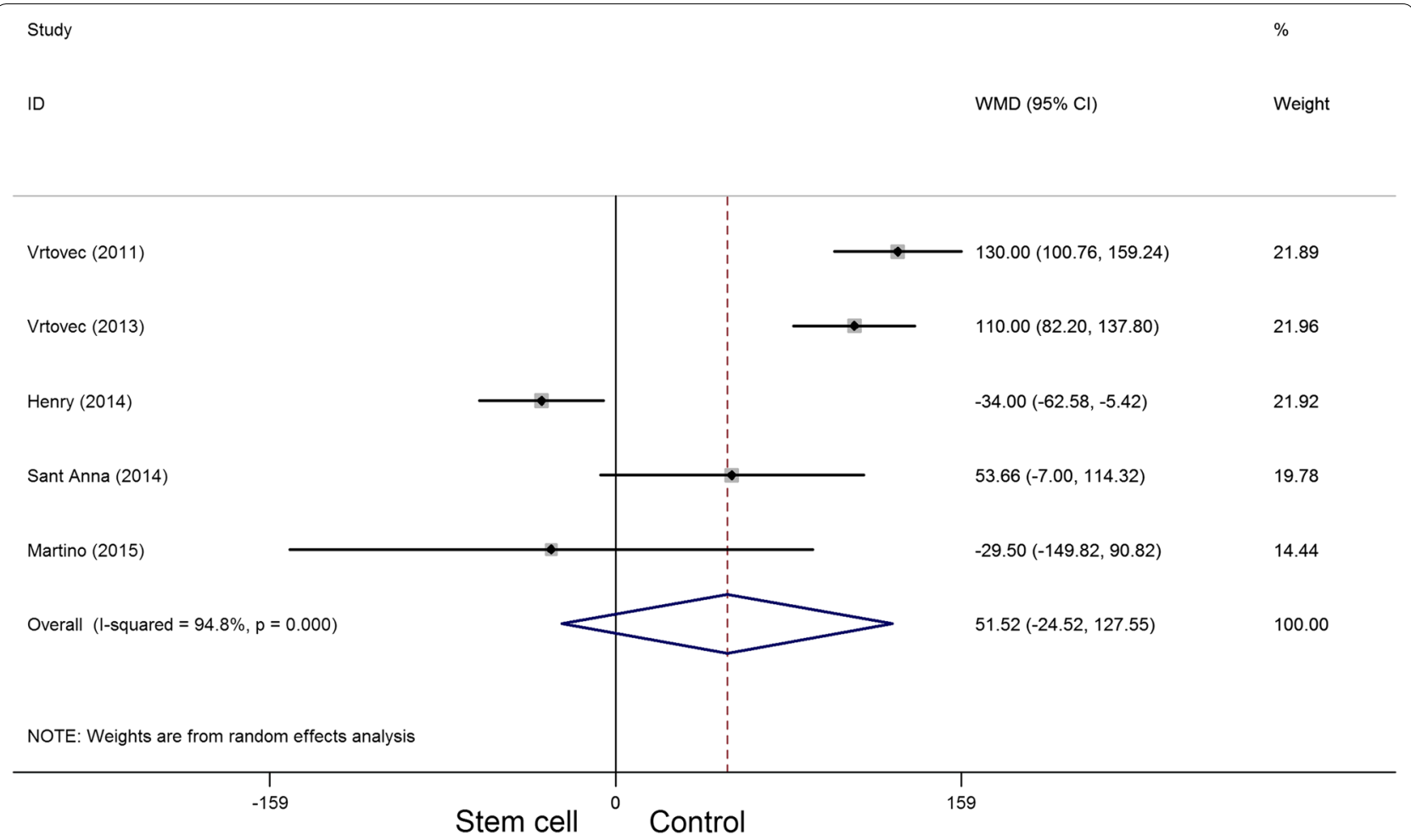

Fig. 8 Forest plot of the 6-min-walk test of stem cell therapy versus controls in patients with dilated cardiomyopathy

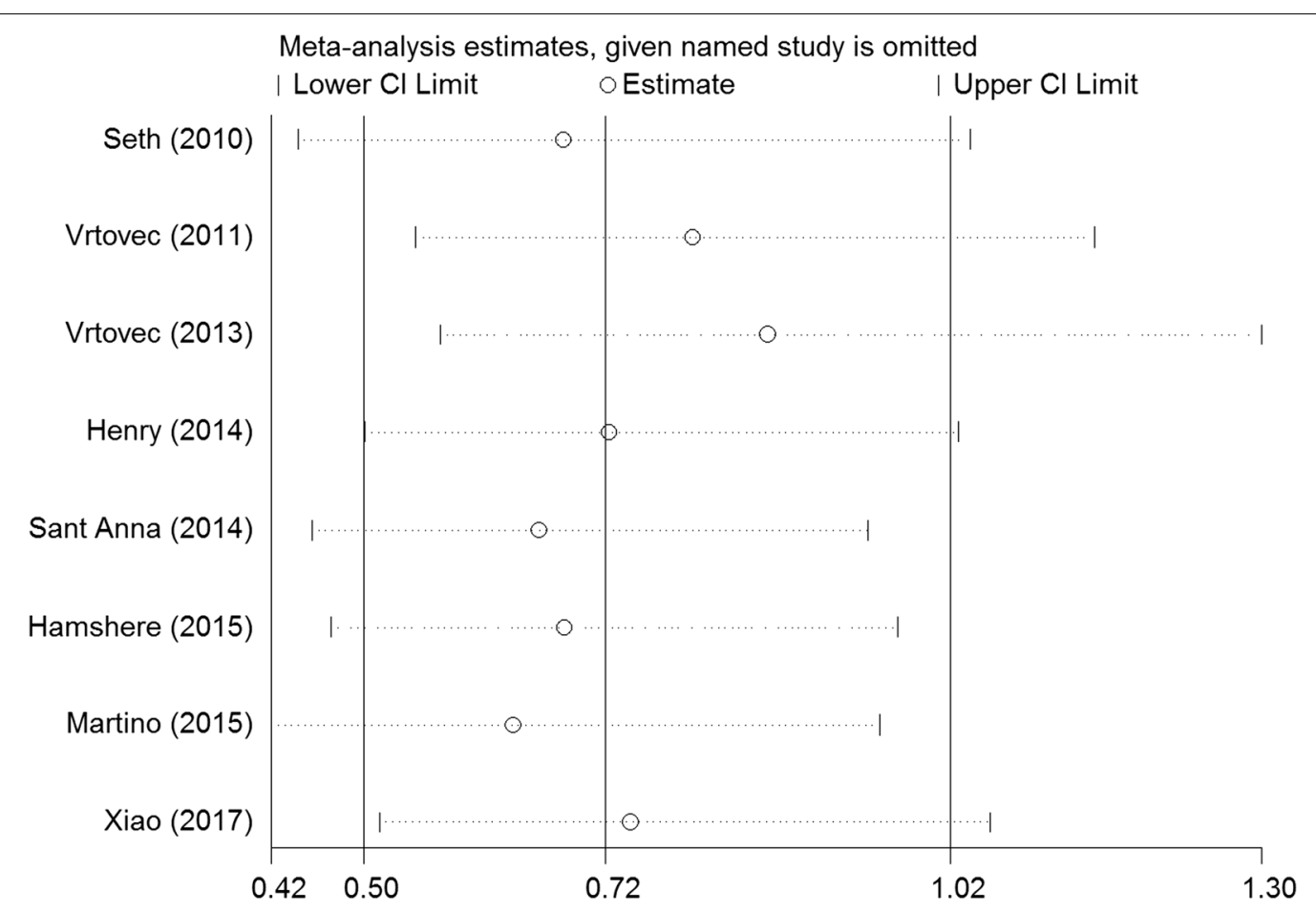

Fig. 9 Sensitivity analysis of the mortality of stem cell therapy versus controls in patients with dilated cardiomyopathy 


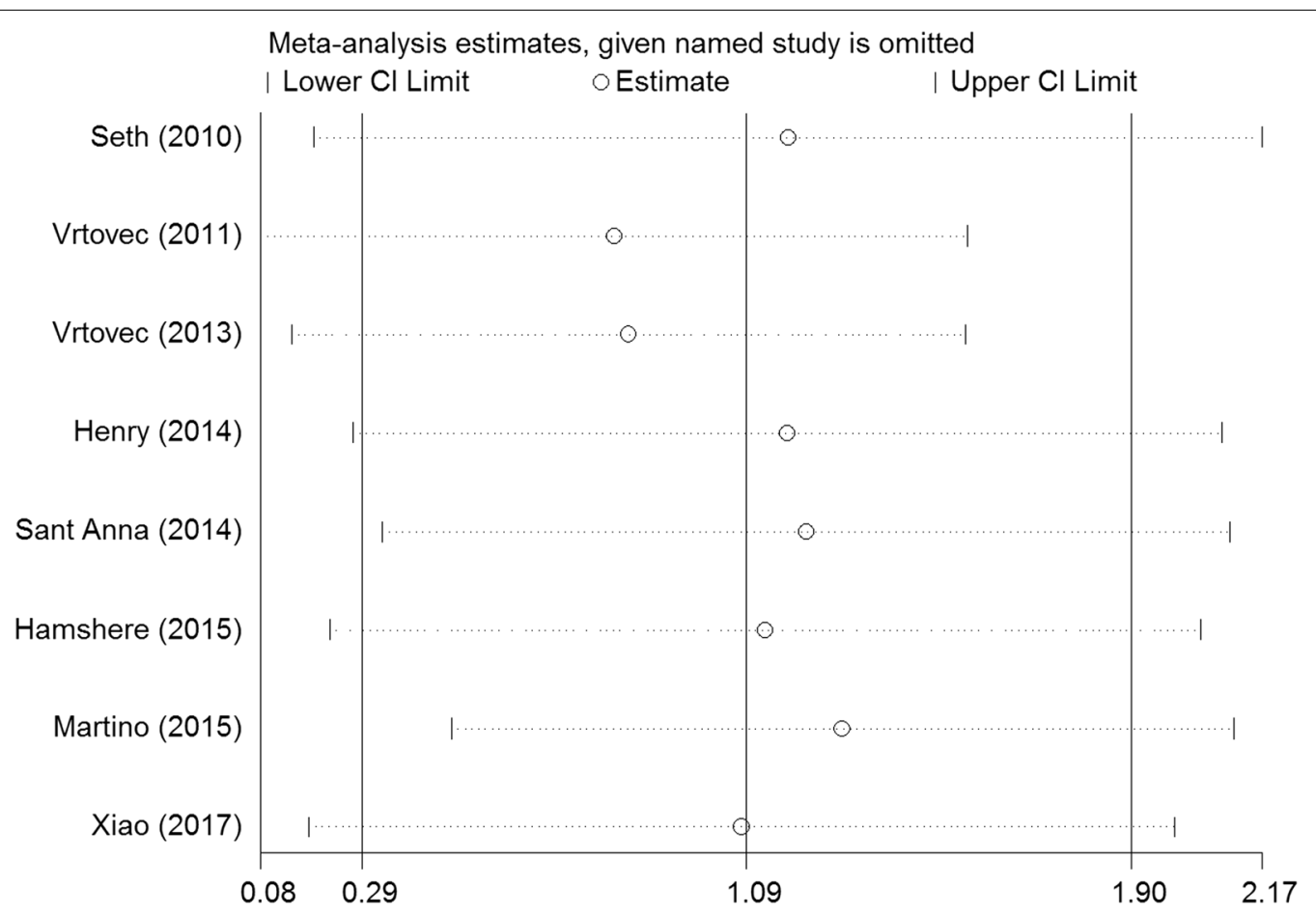

Fig. 10 Sensitivity analysis of the LVEF of stem cell therapy versus controls in patients with dilated cardiomyopathy

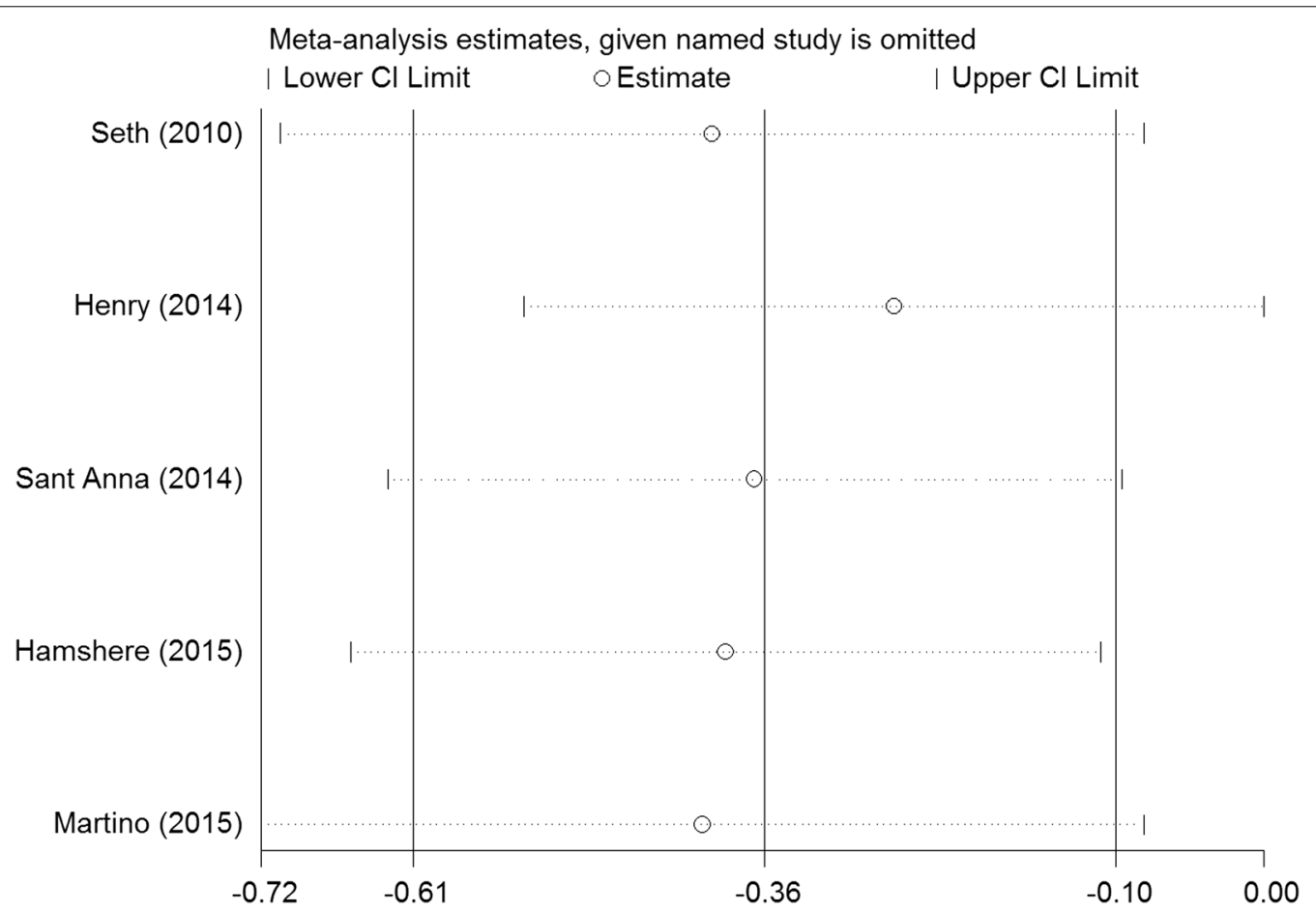

Fig. 11 Sensitivity analysis of the LVESV of stem cell therapy versus controls in patients with dilated cardiomyopathy 


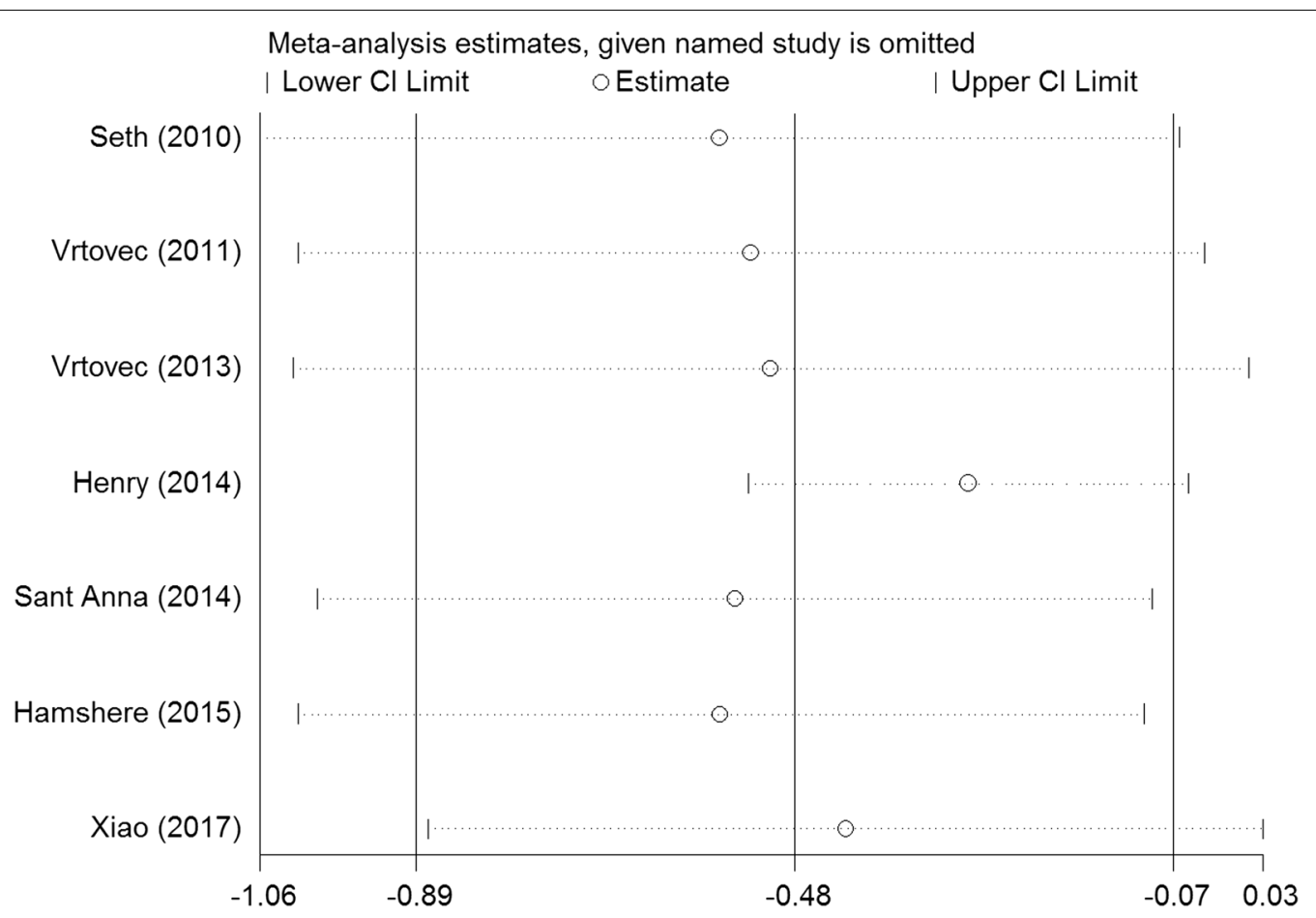

Fig. 12 Sensitivity analysis of the LVEDCS of stem cell therapy versus controls in patients with dilated cardiomyopathy

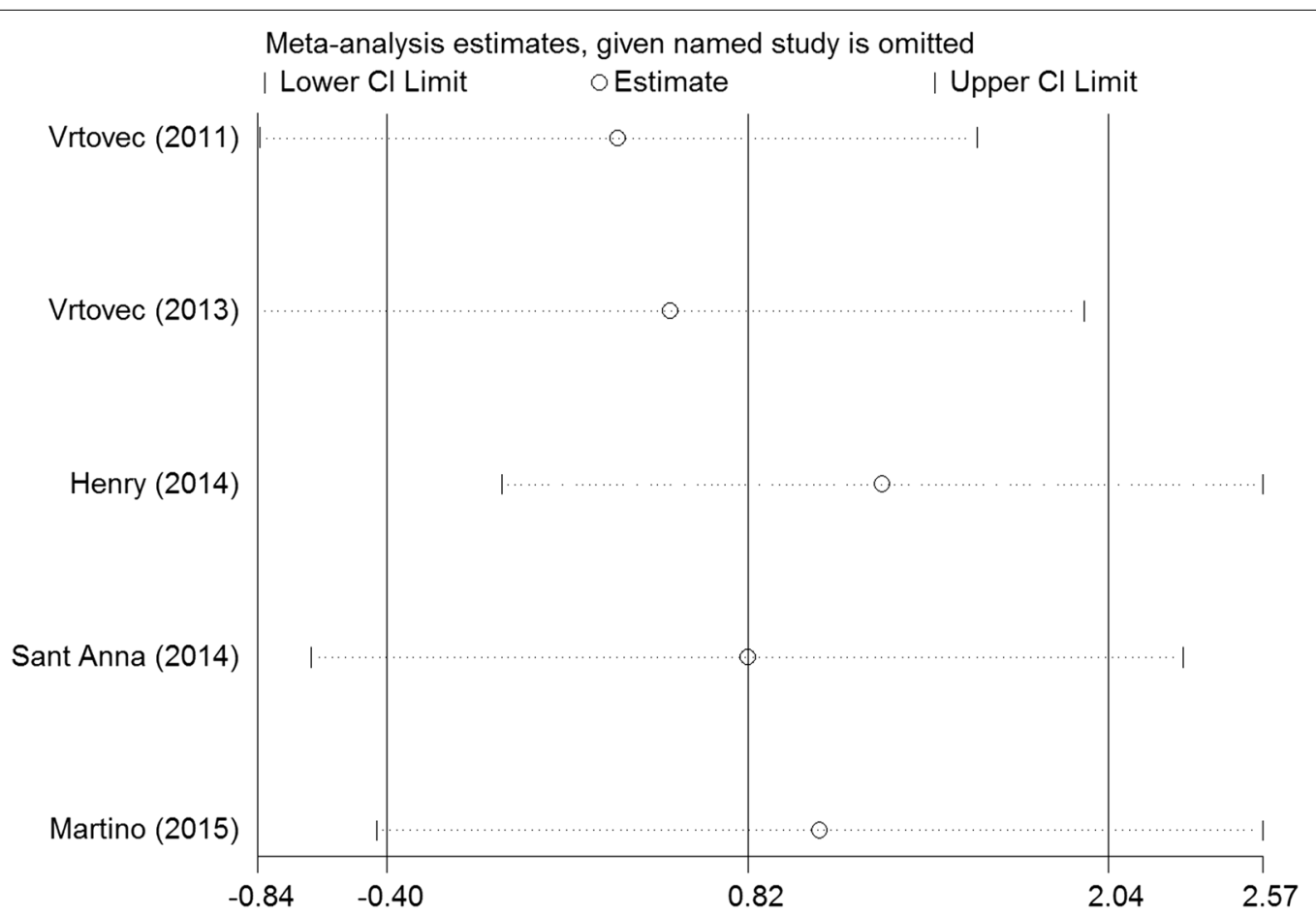

Fig. 13 Sensitivity analysis of the 6-min-walk test of stem cell therapy versus controls in patients with dilated cardiomyopathy 


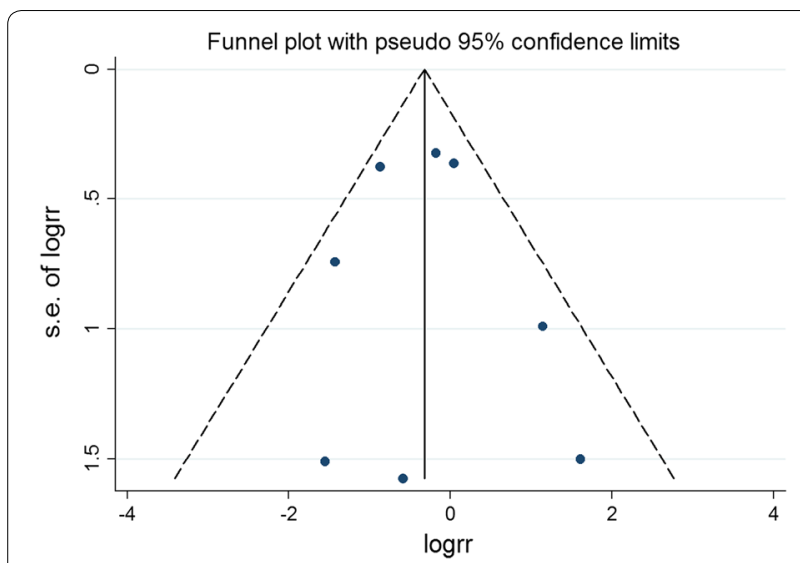

Fig. 14 Funnel plot for publication bias test for the mortality of stem cell therapy
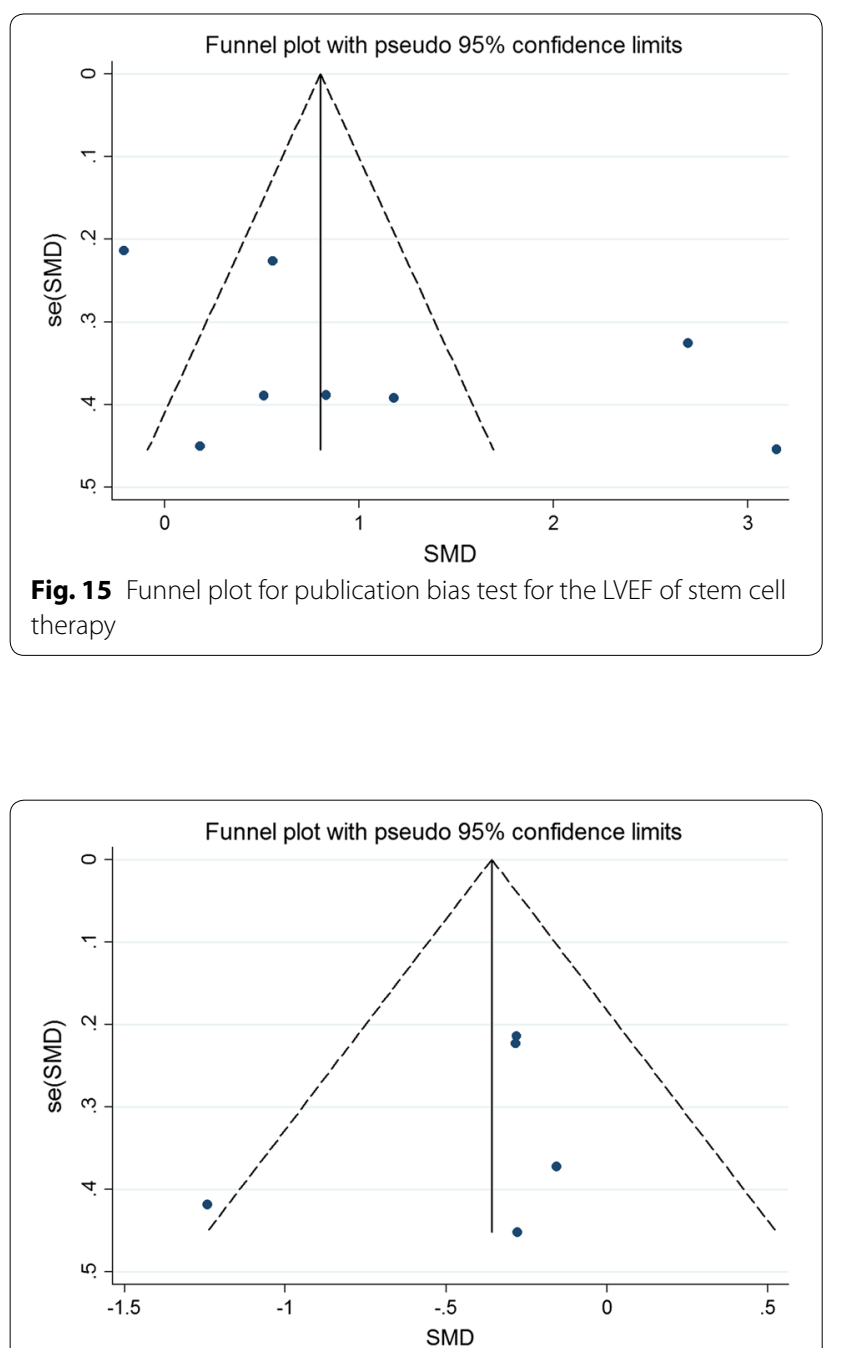

Fig. 16 Funnel plot for publication bias test for the LVESV of stem cell therapy

\section{Discussion}

In this study, we evaluated the efficacy and safety of stem cell therapy in patients with dilated cardiomyopathy by a systematic appraisal and meta-analysis. Our metaanalysis showed that stem cell therapy improves left ventricular ejection fraction and reduces left ventricular end-systolic volume and left ventricular end-diastolic chamber size in patients with dilated cardiomyopathy. However, stem cell therapy has no effect on mortality and exercise capacity. A promising result has been achieved in this systematic appraisal and meta-analysis; stem cell therapy significantly improved LVEF in terms of left ventricular systolic function. Consistently, the final volume of left ventricular contraction and the decrease in ventricular diameter at the end of left ventricular diastolic were observed. Recent studies [27, 28] have also shown that stem cell transplantation can prevent remodeling and stimulate reverse remodeling of left ventricular.

The efficacy and safety of stem cell therapy in patients with dilated cardiomyopathy have been investigated by previous meta-analysis. Recently, Jiao et al. [29] conducted a systematic review and meta-analysis about the efficacy of stem cell therapy in dilated cardiomyopathy. Jiao's study found that stem cell therapy has no effect on LVEDCS; however, our study showed that stem cell therapy significantly improved LVEF and reduced LVESV and LVEDCS. Between-trial heterogeneity is a common problem when interpreting the results of meta-analyses. Heterogeneity was found in the overall comparisons in this study; hence, the random-effects model was used. Different patient selection criteria, intervention options, and time intervals may have influenced the interpretation of heterogeneity.

Dilated cardiomyopathy is an important cause of heart failure. It is a primary myocardial disease with unknown pathogenesis, accompanied by a large number of cardiomyocytes loss, and fibroblast replacement, known as ventricle remodeling $[1,30]$. Therefore, the recovery of non-functional cardiomyocytes is further studied and gained much attention. Beltrami et al. [31] found that myocardial cells were not terminal differentiated cells; however, the number of regenerative cells was far less than the number needed for cardiac repair. Exogenous functional cells transplantation replaces, repairs, or enhances the biological function of nonfunctional cardiomyocytes, i.e., cell development and exploration based on myocardial regeneration therapy, is a promising new strategy for the treatment of cardiovascular diseases [32, 33]. Although global LVEF has been used as the gold standard for measuring cardiac function, especially in large trials such as the CADILLAC trial $[34,35]$, its use in cell therapy trials remains controversial [36]. LVEF is an important predictor of 


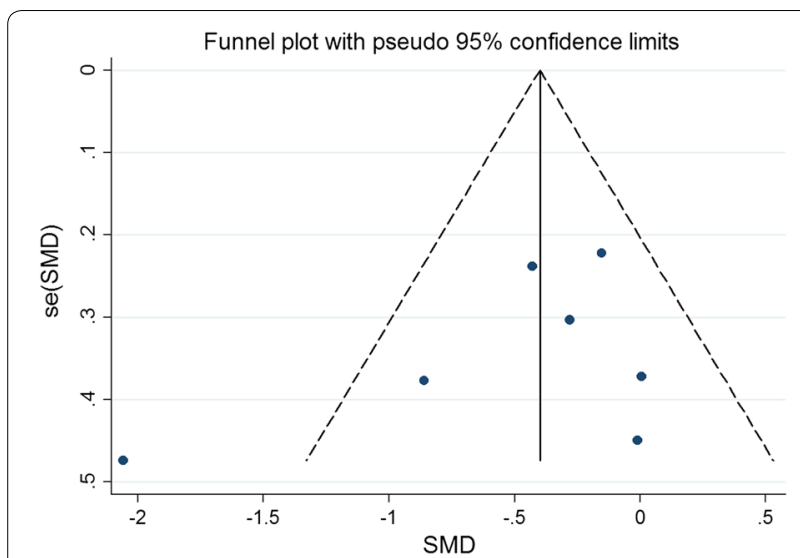

Fig. 17 Funnel plot for publication bias test for the LVEDCS of stem cell therapy

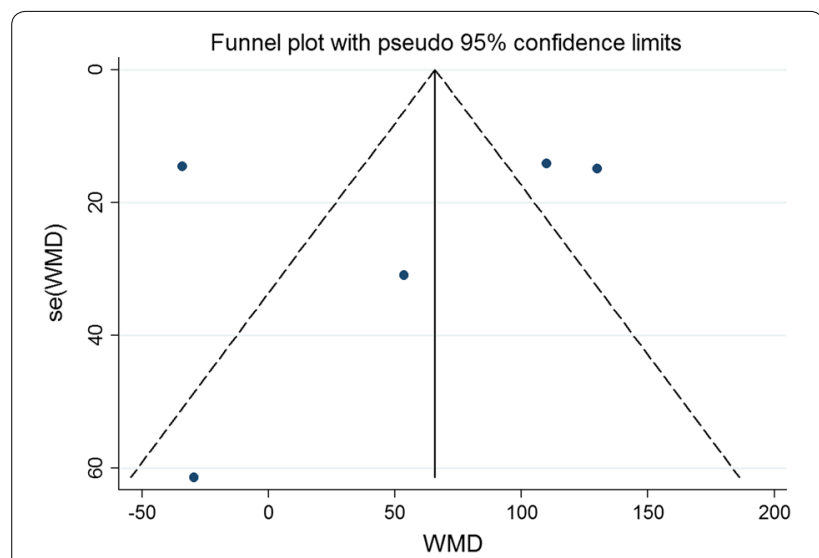

Fig. 18 Funnel plot for publication bias test for the 6-min-walk test of stem cell therapy

mortality in patients with left ventricular dysfunction [37], the cohort of patients included in BMSC trials after AMI $[38,39]$. Consistent with previous studies, we observed a certain degree of improvement in LVEF in this systematic review and meta-analysis, which is conducive to stem cell therapy. Our results demonstrated that stem cell therapy improved LVEF and LVESV in patients with dilated cardiomyopathy. However, stem cell therapy has no effect on mortality ( $R R=0.72,95 \%$ CI 0.50 to 1.02 ) and 6-min-walk test (WMD $=51.52$, $95 \% \mathrm{CI}-24.52$ to 127.55$)$. According to the effect value of the RR and WMD, there was a change trend in favor of stem cell therapy group, although neither of them reached statistical significance. We speculate that this may be related to the small sample size of the included trials (the total sample is less than 300 cases in stem cell therapy group).
At the same time, we noted some limitations in this meta-analysis. Firstly, meta-analysis may be biased when the literature search does not identify all relevant trials or subjectively apply the selection criteria for the trial. To minimize these risks, we conducted thorough searches in multiple bibliographic databases and used clear criteria for research selection, data extraction, and data analysis. Secondly, language can also lead to bias. Specifically, we only chose articles published in English so that other qualified studies published in other language may be excluded. Finally, only a few qualified studies were included. Finally, the number of studies included was relatively small. Only four studies had more than 50 participants in the experimental group in the included studies. The number of participants in most studies was small, so there was a risk of small research biases that could lead to exaggerated effects.

Considering the above problems and limitations, more rigorous clinical randomized controlled trials with larger samples are needed to further verify the role of stem cell therapy in dilated cardiomyopathy patients in the future.

\section{Conclusions}

This meta-analysis suggests that stem cell therapy improves LVEF and reduces LVESV and LVEDCS in patients with dilated cardiomyopathy. However, future well-designed large studies are warranted to clarify the effect of stem cell therapy in patients with dilated cardiomyopathy.

\section{Abbreviations}

WMD: weighted mean difference; SMD: standard mean difference; RR: relative risk; Cl: confidence interval; LVEF: left ventricular ejection fraction; LVESV: left ventricular end-systolic volume; LVEDCS: left ventricular end-diastolic chamber size; RCT: randomized controlled trial.

\section{Acknowledgements}

None.

\section{Authors' contributions}

$X L W, B L, S L R, Z K W, X D Z$ and ZMY wrote the manuscript paper. XLW, BL, SLR and ZKW designed the study. XLW, BL, SLR, XDZ and ZKW collected data, performed some analysis. All authors read and approved the final manuscript.

\section{Funding}

This work was supported by the Key R\&D Project in Shanxi Province (No. 201803D31116), the Shanxi Province Natural Science Foundation (Nos. 2012011040-3, 2013011049-4), the Special Project for Science and Technology Achievements Transformation of Shanxi (No. 201804D131046), the Scientific Research Foundation of High Education Institutions of Shanxi Province (No. 20081 1034), the Research Project of Shanxi Provincial Health and Family Planning Commission (Nos. 201602026, 201602028, and 2017049) and Doctoral Initiation Funding of the Second Hospital of Shanxi Medical University (No. EY2018).

Availability of data and materials Not applicable. 
Ethics approval and consent to participate

Not applicable.

\section{Consent for publication}

Not applicable.

\section{Competing interests}

The authors declare that they have no competing interests.

\section{Author details}

${ }^{1}$ Department of Cardiology, The Second Hospital of Shanxi Medical University, Taiyuan, Shanxi, People's Republic of China. ${ }^{2}$ State Key Laboratory of Oral Diseases, Department of Conservative Dentistry and Endodontics, West China Hospital of Stomatology, Sichuan University, Chengdu, Sichuan, People's Republic of China. ${ }^{3}$ Department of Neonatology, The Second Hospital of Shanxi Medical University, Taiyuan, Shanxi, People's Republic of China.

Received: 27 March 2019 Accepted: 27 June 2019

Published online: 11 July 2019

\section{References}

1. Maron BJ, Towbin JA, Thiene G, et al. Contemporary definitions and classification of the cardiomyopathies: an American Heart Association Scientific Statement from the Council on Clinical Cardiology, Heart Failure and Transplantation Committee; Quality of Care and Outcomes Research and Functional Genomics and Translational Biology Interdisciplinary Working Groups; and Council on Epidemiology and Prevention. Circulation. 2006;113(14):1807-16.

2. Yancy CW, Jessup M, Bozkurt B, et al. 2013 ACCF/AHA guideline for the management of heart failure: executive summary: a report of the American College of Cardiology Foundation/American Heart Association Task Force on practice guidelines. Circulation. 2013;128(16):1810-52.

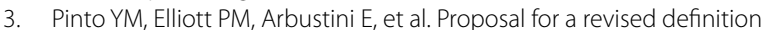
of dilated cardiomyopathy, hypokinetic non-dilated cardiomyopathy, and its implications for clinical practice: a position statement of the ESC working group on myocardial and pericardial diseases. Eur Heart J. 2016;37(23):1850-8

4. Manolio TA, Baughman KL, Rodeheffer R, et al. Prevalence and etiology of idiopathic dilated cardiomyopathy (Summary of a National Heart, Lung, and Blood Institute workshop. Am J Cardiol. 1992;69(17):1458-66.

5. Taylor MR, Carniel E, Mestroni L. Mestroni, cardiomyopathy, familial dilated. Orphanet J Rare Dis. 2006;1:27.

6. Dickstein K, Cohen-Solal A, Filippatos G, et al. ESC Guidelines for the diagnosis and treatment of acute and chronic heart failure 2008: the Task Force for the Diagnosis and Treatment of Acute and Chronic Heart Failure 2008 of the European Society of Cardiology. Developed in collaboration with the Heart Failure Association of the ESC (HFA) and endorsed by the European Society of Intensive Care Medicine (ESICM). Eur Heart J. 2008;29(19):2388-442.

7. Kelkar AA, Butler J, Schelbert EB, et al. Mechanisms contributing to the progression of ischemic and nonischemic dilated cardiomyopathy: possible modulating effects of paracrine activities of stem cells. J Am Coll Cardiol. 2015;66(18):2038-47.

8. Schächinger V, Erbs S, Elsässer A, et al. Intracoronary bone marrowderived progenitor cells in acute myocardial infarction. N Engl J Med. 2006;355(12):1210-21

9. Assmus B, Honold J, Schächinger V, et al. Transcoronary transplantation of progenitor cells after myocardial infarction. N Engl J Med. 2006;355(12):1222-32.

10. Canetti M, Akhter MW, Lerman A, et al. Evaluation of myocardial blood flow reserve in patients with chronic congestive heart failure due to idiopathic dilated cardiomyopathy. Am J Cardiol. 2003;92(10):1246-9.

11. Duran JR, Taffet G. Coronary microvascular dysfunction. N Engl J Med. 2007:356(8):830-40.

12. Fischer-Rasokat $U$, Assmus B, Seeger FH, et al. A pilot trial to assess potential effects of selective intracoronary bone marrow-derived progenitor cell infusion in patients with nonischemic dilated cardiomyopathy: final 1 -year results of the transplantation of progenitor cells and functional regeneration enhancement pilot trial in patients with nonischemic dilated cardiomyopathy. Circ Heart Fail. 2009;2(5):417-23.

13. Widimsky P, Penicka M. Complications after intracoronary stem cell transplantation in idiopathic dilated cardiomyopathy. Int J Cardiol. 2006;111(1):178-9.

14. Vrtovec B, Poglajen G, Sever M, et al. Effects of intracoronary stem cell transplantation in patients with dilated cardiomyopathy. J Card Fail. 2011;17(4):272-81.

15. Beohar N, Rapp J, Pandya S, Losordo DW. Rebuilding the damaged heart: the potential of cytokines and growth factors in the treatment of ischemic heart disease. J Am Coll Cardiol. 2010;56(16):1287-97.

16. Ziebart T, Yoon CH, Trepels T, et al. Sustained persistence of transplanted proangiogenic cells contributes to neovascularization and cardiac function after ischemia. Circ Res. 2008;103(11):1327-34.

17. Martino HF, Oliveira PS, Souza FC, et al. A safety and feasibility study of cell therapy in dilated cardiomyopathy. Braz J Med Biol Res. 2010;43(10):989-95

18. Moher D, Liberati A, Tetzlaff J, Altman DG, PRISMA Group. Preferred reporting items for systematic reviews and meta-analyses: the PRISMA statement. Ann Intern Med. 2009:151(4):264-9.

19. Higgins JP, Altman DG, Gøtzsche PC, et al. The Cochrane Collaboration's tool for assessing risk of bias in randomised trials. BMJ. 2011;343:d5928.

20. Seth S, Bhargava B, Narang R, et al. The ABCD (autologous bone marrow cells in dilated cardiomyopathy) trial a long-term follow-up study. J Am Coll Cardiol. 2010;55(15):1643-4

21. Vrtovec B, Poglajen $G$, Lezaic L, et al. Effects of intracoronary CD34+ stem cell transplantation in nonischemic dilated cardiomyopathy patients: 5-year follow-up. Circ Res. 2013;112(1):165-73.

22. Henry TD, Traverse JH, Hammon BL, et al. Safety and efficacy of ixmyelocel-T: an expanded, autologous multi-cellular therapy, in dilated cardiomyopathy. Circ Res. 2014;115(8):730-7.

23. Sant'Anna RT, Fracasso J, Valle FH, et al. Direct intramyocardial transthoracic transplantation of bone marrow mononuclear cells for nonischemic dilated cardiomyopathy: INTRACELL, a prospective randomized controlled trial. Rev Bras Cir Cardiovasc. 2014;29(3):437-47.

24. Martino H, Brofman $\mathrm{P}$, Greco O, et al. Multicentre, randomized, doubleblind trial of intracoronary autologous mononuclear bone marrow cell injection in non-ischaemic dilated cardiomyopathy (the dilated cardiomyopathy arm of the MiHeart study). Eur Heart J. 2015;36(42):2898-904.

25. Xiao W, Guo S, Gao C, et al. A randomized comparative study on the efficacy of intracoronary infusion of autologous bone marrow mononuclear cells and mesenchymal stem cells in patients with dilated cardiomyopathy. Int Heart J. 2017;58(2):238-44.

26. Hamshere S, Arnous S, Choudhury T, et al. Randomized trial of combination cytokine and adult autologous bone marrow progenitor cell administration in patients with non-ischaemic dilated cardiomyopathy: the REGENERATE-DCM clinical trial. Eur Heart J. 2015;36(44):3061-9.

27. Fatkhudinov T, Bolshakova G, Arutyunyan I, et al. Bone marrow-derived multipotent stromal cells promote myocardial fibrosis and reverse remodeling of the left ventricle. Stem Cells Int. 2015;2015:746873.

28. Yamada S, Arrell DK, Martinez-Fernandez A, Behfar A, Kane GC, PerezTerzic CM, et al. Regenerative therapy prevents heart failure progression in dyssynchronous nonischemic narrow QRS cardiomyopathy. J Am Heart Assoc. 2015. https://doi.org/10.1161/jaha.114.001614.

29. Jiao R, Liu Y, Yang WJ, et al. Effects of stem cell therapy on dilated cardiomyopathy. Saudi Med J. 2014;35(12):1463-8.

30. Karkkainen S, Peuhkurinen K. Genetics of dilated cardiomyopathy. Ann Med. 2007:39(2):91-107.

31. Beltrami AP, Urbanek K, Kajstura J, Yan SM, Finato N, Bussani R, et al. Evidence that human cardiac myocytes divide after myocardial infarction. N Engl J Med. 2001;344(23):1750-7. https://doi.org/10.1056/NEJM200106 073442303.

32. Nagaya N, Kangawa K, Itoh T, et al. Transplantation of mesenchymal stem cells improves cardiac function in a rat model of dilated cardiomyopathy. Circulation. 2005;112(8):1128-35.

33. Seth $\mathrm{S}$, Narang R, Bhargava B, et al. Percutaneous intracoronary cellular cardiomyoplasty for nonischemic cardiomyopathy: clinical and histopathological results: the first-in-man ABCD (autologous bone marrow cells in dilated cardiomyopathy) trial. J Am Coll Cardiol. 2006;48(11):2350-1. 
34. Cox DA, Stone GW, Grines CL, et al. Outcomes of optimal or "stent-like" balloon angioplasty in acute myocardial infarction: the CADILLAC trial. J Am Coll Cardiol. 2003;42(6):971-7.

35. Aviles RJ, Askari AT, Lindahl B, et al. Comparison of angioplasty with stenting, with or without abciximab, in acute myocardial infarction. N Engl J Med. 2002;346(13):957-66.

36. Traverse $\mathrm{JH}$, Henry TD, Moye' LA. Is the measurement of left ventricular ejection fraction the proper end point for cell therapy trials? An analysis of the effect of bone marrow mononuclear stem cell administration on left ventricular ejection fraction after ST-segment elevation myocardial infarction when evaluated by cardiac magnetic resonance imaging. Am Heart J. 2011;162(4):671-7.

37. Solomon SD, Anavekar N, Skali H, et al. Influence of ejection fraction on cardiovascular outcomes in a broad spectrum of heart failure patients. Circulation. 2005;112(24):3738-44.
38. Clifford DM, Fisher SA, Brunskill SJ, et al. Stem cell treatment for acute myocardial infarction. Cochrane Database Syst Rev. 2012;15(2):CD006536.

39. Clifford DM, Fisher SA, Brunskill SJ, et al. Long-term effects of autologous bone marrow stem cell treatment in acute myocardial infarction: factors that may influence outcomes. PLoS ONE. 2012;7(5):e37373.

\section{Publisher's Note}

Springer Nature remains neutral with regard to jurisdictional claims in published maps and institutional affiliations.
Ready to submit your research? Choose BMC and benefit from:

- fast, convenient online submission

- thorough peer review by experienced researchers in your field

- rapid publication on acceptance

- support for research data, including large and complex data types

- gold Open Access which fosters wider collaboration and increased citations

- maximum visibility for your research: over $100 \mathrm{M}$ website views per year

At BMC, research is always in progress.

Learn more biomedcentral.com/submissions 